\title{
LAND REFORM EMBEDDED IN THE CONSTITUTION: LEGAL CONTEXTUALISATION
}

\author{
Juanita M Pienaar \\ Private Law \\ Stellenbosch University
}

\begin{abstract}
Land reform is a temporal process that was embarked on in two distinctive phases in South Africa: first by way of an exploratory programme before the new constitutional dispensation commenced, followed by, secondly, an all-encompassing programme after April 1994. While a constitutional dimension distinguished these broad phases from each other, the second phase was furthermore characterised by having an interim Constitution for a period of time, followed by the final Constitution, which is currently still in place. With regard to land reform, the initial exploratory programme was conducted in the absence of a Constitution with a Bill of Rights. Following 1994 and the commencement of a Constitution, the interim property clause, section 28, did not provide for land reform specifically, although provision was made for the expropriation of property for public purposes. However, provision was made, specifically for the restitution of land and rights in land, but not within the property clause as such. In contrast, the final property clause, section 25 which commenced in 1997, provides for land reform in particular. This contribution explores the meaning of having land reform embedded in the Constitution generally and in the property clause specifically. To that end it becomes clear that being embedded in the property clause calls for a specific approach to and interpreting of all land reform-based and -related statutory measures and case law. It is also imperative that the structure of the property clause and the prominence of the reform-oriented clauses be taken into account when considering the property clause on the one hand and the aims and purposes of land reform, on the other. While this contribution focuses entirely on the constitutional dimension of land reform, it is also true that effective policy measures and legislation, implemented, interpreted and applied correctly, are furthermore nonnegotiable to make land reform effective, although they are not analysed here.
\end{abstract}

Key Words: Land Reform; Constitution; Restitution; Redistribution; Tenure Reform; Property Clause; Legal Implications

\section{Introduction}

South Africa is a democracy within a constitutional dispensation. ${ }^{1}$ This has implications for everything we do in our country: how we approach and structure our endeavours, how we

Ex Parte Chairperson of the Constitutional Assembly: In re Certification of the Constitution of the Republic of South Africa 1996 (4) SA 744 (CC). While this contribution does not deal with political undercurrents and considerations underlying the Constitution and the land reform programme embedded therein per se, it suffices to say that in the present democracy parliamentary sovereignty has been replaced by constitutional sovereignty and that the Constitution is paramount. Supporting and protecting the South African constitutional 
formulate our aims and goals and how we develop the mechanisms and tools employed to achieve the stated aims and goals. Forming the centre of our dispensation is the Constitution, ${ }^{2}$ consisting of a Bill of Rights ${ }^{3}$ and constitutional principles and values. ${ }^{4}$ When land reform was first embarked on in the pre-constitutional phase on an exploratory basis, no Bill of Rights or property clause guided or undergirded reform. Following the new constitutional dispensation, property law reform was guided by an interim property clause that did not provide for land reform specifically. In contrast, the present Constitution now provides for land reform in particular, coupled with the imperative to reform other natural resources as well. Why is this important? Could land reform not be embarked on and conducted in the absence of a Constitution or a property clause? Does it make any difference that the present South African land reform programme is embedded in the Constitution? While it is true that land reform is complex and multi-dimensional, including the reasons leading up to formulating the property clause on the one hand and the overall land reform programme on the other, and while it is true that various political, economic, developmental and philosophical debates, undercurrents and considerations emerge, not all of these issues and considerations can be canvassed here. Instead, this contribution explores the meaning of having land reform embedded in the Constitution generally and in the property clause specifically, in view of its legal ramifications only. It is within this context that the relevant background and more importantly, the current legal parameters and implications, are explored here.

Being integral to the topic at hand, the concept 'land reform' will be explored first. In this regard much emphasis will be placed on South African considerations and what the concept means in our context. That will be followed by an overview of what the Constitution provides for with respect to land reform. The particular implications of having land reform embedded in the Constitution, thereby transforming the South African land reform programme to a rather unique operation compared to other programmes globally, are dealt with thereafter.

\section{'Land Reform'}

The term is often used and referred to in popular media and academic publications. While some form of universality may be incorporated into the term, it is crucial to bear in mind that there is no fixed definition of land reform or no single definition that would suffice in all circumstances. ${ }^{5}$ Instead, 'land reform' is a flexible and adaptable term that is largely influenced by the particular background of a specific jurisdiction or country that employs it. To a large extent, the meaning of the term 'land reform' reverts back to the reasons that gave rise to it. Accordingly, aims and goals, usually linked to the reasons for employing

democracy are various Chapter 9 institutions, e.g., the Office of the Public Protector and the Human Rights Commission.

2 The interim Constitution (Act 200 of 1993) commenced on 27 April 1994 and the final, current Constitution, commenced on 4 February 1997. See for a historical background Woolman and Swanepoel, "Constitutional History" in Woolman, Roux and Bishop (eds.) Constitutional Law of South Africa (2009), second edition, whole of Chapter 2. See also Devenish, Commentary on the South African Constitution (1998) for the content of the interim Constitution.

3 See for more detail Cheadle, Davis and Haysom, South African Constitutional Law (2005).

4 For operational provisions in the Constitution see Woolman "Application" in Woolman, Roux and Bishop (eds.) Constitutional Law of South Africa (2009), second edition, Chapter 31.

$5 \quad$ See Pienaar Land Reform 2014:12-15. 
land reform in the first place, would inevitably impact on the definition, scope and mechanisms of the particular land reform programme. To that end, different jurisdictions at different points in time, with diverse backgrounds, would consider and ultimately employ land reform differently. ${ }^{6}$ Apart from the specific historical background, ${ }^{7}$ other factors that also guide the content and definition of land reform are underlying ownership, economic and agrarian patterns and paradigms. ${ }^{8}$

Because 'land reform' also embodies the word 'reform', it implies that the action or method requires some adjustment to the existing paradigm or status quo, usually on the grounds of fairness and efficiency. ${ }^{9}$ Land reform is thus usually embarked on because it is aimed at a more fair or equitable dispensation or a better, more efficient, outcome. ${ }^{10}$

Internationally land reform is usually reduced to "the redistribution of property or rights in land for the benefit of the landless, tenants and farm labourers." 11 This means that traditionally, land reform is essentially linked to agriculture and agricultural reform. In fact, land reform and agricultural reform have often been used inter-changeably. ${ }^{12}$ Regarding the content, land reform has also been described as reforms that aim to increase the ability of persons to gain access to land ${ }^{13}$ and to vest secure rights in relation to land. ${ }^{14}$ Apart from the redistribution dimension, some jurisdictions, including South Africa, also enjoin restorative elements. ${ }^{15}$ Given the South African history of dispossession, the restoration dimension is especially prominent. ${ }^{16}$

Apart from the specific historical reasons that gave rise to land reform in particular jurisdictions, ${ }^{17}$ land reform has generally been employed on a global scale to achieve two

See e.g. Dorner, Latin American land reform 1992:3-4 with regard to land reform in Latin America.

In South Africa the racially discriminatory land control system before 1991 was instrumental in embarking on an in-depth land reform programme. See for more detail Woolman and Swanepoel, "Constitutional History" in Woolman, Roux and Bishop (eds.) Constitutional Law of South Africa (2009), second edition, 2-5-2-23; Van der Merwe, "Land tenure in South Africa: a brief history and some reform proposals" 1989 TSAR 663692; Bennett, “African land - a history of dispossession” in Zimmermann and Visser (eds.), Southern Cross 1996:81-80 and Klopper and Pienaar, "The historical context of land reform in South Africa and early policies" 2014 PER 20 1-21.

$8 \quad$ Pienaar, Land Reform 2014:17-19.

9 Lipton, Land reform in developing countries 2011:323-324.

10 Murisa and Helliger, "Contemporary rural realities in Southern Africa" in Helliger and Murisa (eds.), Land struggles in Civil Society in Southern Africa 2011:1-43.

11 Lipton, Land reform in developing countries 2011:323.

12 Van der Westhuizen, "Land reform: lessons from a south-eastern Free State experience" 2005 SA Tydskrif vir landbouvoorligting 1-10, 2.

13 This is often referred to as redistribution in general terms.

14 This is linked to adjusting the form of tenure or control a particular person or community has with regard to land and immovable property, constituting tenure reform.

15 Langford and Moyo, "Right, remedy or rhetoric? Land restitution in international law" 2010 Nordic Journal of Human Rights 143-176.

16 Hall, "Reconciling the past, present and future" in Walker, Bohlin, Hall and Kepe (eds.), Land, Memory, Reconstruction and Justice: Perspectives on Land Claims in South Africa 2010:17-40. In South Africa the restitution programme, provided for in section 25(7) of the Constitution, is one of the three sub-programmes. The other sub-programmes embody redistribution and tenure reform.

17 In South Africa the racially-based land control system and its aftermath are directly linked to the land reform programme. See for a detailed historical exposition Pienaar, Land Reform 2014:chapter 3. 
main goals, namely to (a) reduce poverty ${ }^{18}$ and to (b) address gross inequality. ${ }^{19}$ These overarching goals are usually supplemented and supported by other goals, including ${ }^{20}$

(a) promoting output, efficiency and growth in the agricultural sector; ${ }^{21}$

(b) enhancement of the environment and environmental sustainability; and

(c) enabling peace and stability, in general.

In light of the above, it becomes clear that achieving particular land reform goals is often also linked to overarching international goals, including the Millennium Development Goals, ${ }^{22}$ or particular overarching national objectives, including those contained in the South African National Development Plan. ${ }^{23}$

Often the goals the government sets out to achieve overlap with the benefits beneficiaries intend to gain, but sometimes they are grossly contradictory. ${ }^{24}$ For example, while land reform may have been employed to prevent instability and upheavals and, instead, to guarantee peace and progress, ${ }^{25}$ beneficiaries may be interested only in their own personal gains and not at all concerned about regional or national considerations. For the

18 Hall, "Transforming rural South Africa? Taking stock of land reform" in Ntsebeza and Hall (eds.), The land question 2007:87-106; Bernstein, "Agrarian questions of capital and labour: some theory about land reform (and a periodization)" in Ntsebeza and Hall (eds.), The land question 2007:29-30. Vulnerability and poverty are also often linked with fluctuations across life cycles, e.g., after death of the breadwinner - see also Statistics South Africa Men, women and children: findings of the living conditions survey (2013) which indicates that more than two-thirds $(67,9 \%)$ of all households are located in urban areas, p. 9. Generally, more than one out of every five $(21,2 \%)$ are living below the food poverty line, a third $(32,3 \%)$ are living below the lower-bound poverty line and slightly less than half $(45,1 \%)$ of adults are living below the upper-bound poverty line - p. 15 . Across all provinces, women are more likely to be poorer than men - p. 18 .

19 Ntsebeza, "Land redistribution in South Africa: the property clause revisited" in Ntsebeza and Hall (eds.), The land question 2007:107-131, 125; Lipton, Land reform in developing countries 2011:16.

20 See generally Pienaar, Land Reform 2014:23-25.

21 Interestingly, in the initial policy drafting processes, food security was not highlighted in particular - see Hall, "Two cycles of land policy in South Africa: Tracing the contours" in Anseeuw and Alden (eds.), The Struggle over land in Africa: Conflicts, Politics and Change 2010:175-192. More recently, since 2000, with greater emphasis on the eradication of poverty and improving food security, a new developmental paradigm for land reform emerged - see Riddle, "Contemporary thinking on land reform" (2000)

http://www.fao.org/sd/ltdirect/ltan0037.htm\#topofpage [date of use 27 February 2014]. Food security has also enjoyed more attention in South Africa in recent policy documents, including the 2011 Green Paper on Land Reform - see Pienaar, "Mechanics of intervention and the Green Paper on Land Reform" 2014 PER 21. This new developmental paradigm is focused not only on the landless, but is also aimed at strengthening the economic and productive potential of all producers, including existing producers - see also the following governmental policy documents: Policy Framework for the Recapitalisation and Development Programme; State Land Lease and Disposal Policy Framework and Agricultural Landholding Policy Framework - all published on 23 July 2013.

22 Goal 7 of the Millennium Development Goals, adopted by the United Nations during the United Nations Millennium Summit in New York in 2000, deals with environmental sustainability and includes Target 11, which is aimed at eradicating poverty and improving livelihoods. In this regard the international dimension of land reform emerges - see for a detailed discussion of this dimension Pienaar, Land reform 2014:673-674 and with regard to the Millennium Goals 39.

23 The South African National Development Plan was published in August 2012 by the Planning Commission. Some of the main objectives of the Plan include the elimination of poverty and the reduction of inequality by 2030. Although the National Development Plan, as such, is not aimed at land reform specifically, it certainly has links therewith - see for a discussion of these links Pienaar, Land reform 2014:237-241.

25 Walker, "Redistributive land reform: for what and for whom?" in Ntsebeza and Hall (eds.), The land question 2007:132-151;134. 
government productivity and development may be important objectives, ${ }^{26}$ but for a particular individual obtaining closure and returning to her roots may be the only considerations. ${ }^{27}$ With regard to the specific individual, productivity, sustainability and development may not even enter the picture. $^{28}$

It is also important to note that land reform is not the automatic solution to all economic, developmental, social and political challenges. Instead, one has to be realistic and accept that land reform has limits. ${ }^{29}$ While it is true that land reform may not achieve the broad spectrum of goals listed above, it is also true that not all of the benefits of land reform may be quantifiable, measured and weighed. Indeed, some benefits are tangible, for example determining how much land had been redistributed and to whom. Other benefits may be of more symbolic relevance, contributing to identity and a sense of well-being, belonging and community. ${ }^{30}$

With regard to land and property in particular, the historical background encapsulating the three pillars of apartheid in the form of influx control, ${ }^{31}$ group areas ${ }^{32}$ and the strict regulation of unlawful occupation of land, ${ }^{33}$ indicate clearly the preferred international definition of land reform, which essentially entails the redistribution of agricultural land only, is too narrow for South African conditions. Instead, within the South African context land reform can be described as the ${ }^{34}$

initiatives, embodied in legislative, policy and other measures, constituting actions and mechanisms aimed at broadening access to land, improving security of tenure and restoring land or rights in land. Overall, embodied in this concept is the operational as well as the supportive and supplementary frameworks, including relevant strategies, papers, plans and implementing frameworks.

This means that while the South African land reform programme may share some similarities with other land reform programmes that have been conducted globally, ${ }^{35}$ with regard to its definition, content and scope, it is rather unique. In this regard three separate, but inter-connected sub-programmes may be identified, namely (a) redistribution - or

${ }^{26}$ In South Africa these objectives are increasingly becoming more prominent, see e.g. Du Toit, "Comment on the newly released Green Paper on Land Reform" 26 September 2011, PLAAS and Department of Rural Development and Land Reform Policy Framework for the Recapitalisation and Development Programme 23 July 2013.

27 Lipton, Land reform in developing countries 2011:58.

28 Bohlin, "A price on the past: Cash as compensation in South African land restitution" 20043 Canadian Association of African Studies 672-687.

29 Pienaar, Land Reform 2014:37-38.

30 Gibson, "Land redistribution/restitution in South Africa: a model of multiple values as the past meets the present" 2010 British Journal of Political Science 135-169.

31 Embodied in inter alia the Black (Urban Areas) Act 21 of 1923 and the Black (Urban Areas) Consolidation Act 25 of 1945. Both legislative measures were initially published as "Native" and were later amended. Embodied in the Group Areas Act 41 of 1950 and its successors.

33 Embodied in the Prevention of Illegal Squatting Act 52 of 1951. See for more detail Pienaar, Land Reform 2014:104-112; Van Wyk, Planning Law 2012:40; Muller, "The legal-historical context of urban forced evictions in South Africa" 2013 Fundamina 367-396 and Huchzermeyer, "From 'contravention of laws' to 'lack of rights': redefining the problem of informal settlements in South Africa" 2004 Habitat International 333-347.

34 Pienaar, Land Reform 2014:15.

35 E.g., partial and fully fledged land reform programmes in Australia - see Reilly, "Land rights for disenfranchised and dispossessed peoples in Australia and South Africa: a legislative comparison" 2001 Queensland Law Journal 41. 
broadening access to land; ${ }^{36}$ (b) tenure reform - or upgrading or making insecure and weak rights stronger and more secure $;^{37}$ and (c) restitution - or restoring what was lost and dispossessed under a racially-based land control system. ${ }^{38}$

The brief background above has indicated that particular needs and demands, some shared at a global level with other jurisdictions, but others quite unique to South Africa, necessitated an all-encompassing land reform programme. Not only is the South African land reform programme more expansive than other programmes embarked on globally, but it also has a very particular constitutional dimension, dealt with in more detail below.

\section{The Constitutional Dimension}

In the context of land reform a clear distinction may be made between a racially-based land control system functioning on a discriminatory basis on the one hand ${ }^{39}$ and embarking on a land reform programme on the other. However, land reform in its present guise did not commence overnight. ${ }^{40}$ Instead, South Africa approached land reform in two distinct phases: firstly, an initial or exploratory land reform programme not guided by a Bill of Rights which was followed by, secondly, an in-depth, all-encompassing land reform programme, undergirded by the Constitution, which is still being conducted.

While it is critical to understand that the re-assessment of the land control system did not take place in isolation, but was impacted on and influenced by political and economic considerations as well, these issues are not explored here. ${ }^{41}$ Suffice it to say that, for example, where political pressure increased, greater pressure to change, adapt and transform land rights, resulted. In this regard the removal of the racial dimension led to free settlement areas, thereby negating the former group areas policies and approaches. ${ }^{42}$

The initial or exploratory phase started under the former De Klerk government with the publication of the White Paper on Land Reform in 1991 and the promulgation of a set of reformative statutes. ${ }^{43}$ While these steps were urgently needed in $1991,{ }^{44}$ the land reform

\footnotetext{
36 Section 25(5) of the Constitution. See Pienaar, Land Reform 2014:chapter 7.

37 Section 25(6) of the Constitution, read with section 25(8). See Pienaar, Land Reform 2014:chapter 8.

38 Section 25(7) of the Constitution. See Pienaar, Land Reform 2014:chapter 9.

39 See for an exposition of the immediate impact of such a discriminatory approach to land Judge Sachs' background to the Prevention of Illegal Eviction from and Unlawful Occupation of Land Act 19 of 1998 in Port Elizabeth Municipality v. Various Occupiers 2004 (12) BCLR 1268 (CC); 2005 (1) 217 (CC). See also Kloppers and Pienaar, "The historical context of land reform in South Africa and early policies" 2014 PER 20 and Huchzermeyer, "From 'contravention of laws' to 'lack of rights': redefining the problem of informal settlements in South Africa" 2004 Habitat International 333-347.

40 Hall, "Two cycles of land policy in South Africa: Tracing the contours" in Anseeuw and Alden (eds.), The Struggle over land in Africa: Conflicts, Politics and Change 2010:175-192.

41 See generally Feinstein, Economic History of South Africa (2005); Sparks, The mind of South Africa (2007); Giliomee, The Afrikaners: biography of a people (2003); Beinart, Twentieth century South Africa (2001). Beinart, Twentieth century South Africa 2001:357; Marais, South Africa pushed to the limit 2011:27-38.

${ }^{43}$ See for background Pienaar, Land Reform 2014:153-162; Van der Walt, "Towards the development of postapartheid land law: an exploratory survey" 1990 De Jure 38-40; Van der Merwe and Pienaar, "Land reform in South Africa" in Jackson and Wilde (eds.), Reform of property law 1997:350.

44 Apart from the fact that the racially discriminatory dimension of land control had to be removed, the land control system overall was rather fragmented, diverse, complex and insufficient - see Olivier, Du Plessis and Pienaar, "Legislation affecting land: an overview" 1990 SA Public Law 266-276; Van Wyk, Planning law 2012:46; Cobbett "The land question in a post-apartheid South Africa: a preliminary assessment" in Cross and Haines (eds.), Towards freehold 1988:60-73.
} 
initiatives were rather superficial and restricted in scope and impact. Following the repeal of all racially-discriminatory land measures under the Abolition of Racially-Based Land Measures Act 108 of 1991, a limited upgrading process ${ }^{45}$ was initiated and a restricted land restitution process was announced. ${ }^{46}$

The immediate effect of the 1991 initiatives was disappointing. It resulted in an even more complex, ${ }^{47}$ diverse land control system, ${ }^{48}$ embodying a continued fragmented approach to land use, planning, survey, deeds and registries. ${ }^{49}$ Physically, South Africa was still a country divided: it consisted of four national states: Transkei, Ciskei, Bophuthatswana and Venda; six self-governing territories, ${ }^{50}$ and four provinces: the former Transvaal, Natal, Orange Free State and Cape provinces. Accordingly, deracialising the land control system - though critical - was not sufficient. With regard to land and property much more had to be done. What was needed was an all-encompassing land reform programme that also provided for:

- broadening access to land or the opening up of all natural resources to everyone;

- making insecure or weak rights stronger; and

- restoring what was lost or dispossessed - on a much larger scale.

Within the context of land control, an urgent need to rationalise and re-align diverse land administration systems that prevailed in the different areas alluded to above, also emerged. To that end not only the land control system, but also its supporting networks and underlying systems, including the survey of land and the recording of rights in land, had to be re-assessed on a national scale. ${ }^{51}$

While the above-mentioned shortcomings hindered the effectiveness of the exploratory land reform initiatives, the fact that these efforts were not constitutionally-grounded, was especially disconcerting. Therefore, apart from the scope and degree on which land reform was undertaken, the further distinguishing factor of the second, more encompassing phase was that land reform was embedded in the Constitution. Because South Africa promulgated two Constitutions - first an interim and thereafter a final Constitution as alluded to above, two further dimensions to land reform emerged. In this regard a less-focused and lessreform centred approach was embodied in section 28 of the interim Constitution (the then property clause), whereas a clearly more reform oriented and more expansive reform approach is embodied in section 25 of the final Constitution (the current property clause). While the main emphasis of this contribution remains on the present Constitution and its

45 Embodied in the Upgrading of Land Tenure Rights Act 112 of 1991.

46 An Advisory Commission on Land Allocation was established under sections 89-96 of the Abolition of Racially Based Land Measures Act 108 of 1991 to advise the then State President on, inter alia, the restoration of land to persons and communities that had been removed in terms of the (repealed) racially discriminatory land system.

47 Different kinds of rights prevailed in different areas in the country at different points in time - see the exposition in Pienaar, Land Reform 2014:142-153.

48 Not only were rights linked to race and cultural backgrounds, but also to location and region. A multitude of different kinds of rights with diverse implications resulted. Accordingly, de-racialising land rights did not automatically address the diversity-factor of the land control system.

49 See for detail Pienaar, Land Reform 2014:158-160. Not only were the actual rights diverse, but how the land was surveyed and how the titles were ultimately registered and recorded, differed from area to area, depending on whether it was a national state, a self-governing territory or a province. KwaZulu, KaNgwane, QwaQwa, KwaNdebele, Gazankulu and Lebowa.

51 Olivier, Du Plessis and Pienaar, "Legislation affecting land: an overview" 1990 SA Public Law 266-276. 
implications specifically for land reform, a brief reference to the interim Constitution is necessary in order to appreciate the main differences between the two property clauses and their relevance for land reform. To that end considerations relating to political and economic debates and undercurrents - though important - are not further explored here. ${ }^{52}$

\section{Section 28 in the Interim Constitution}

Incorporating a property clause in the Constitution was a contentious issue. In the debate both spectrums were represented: $:^{53}$ proponents in support of incorporating a property clause in the Bill of Rights as well as persons in favour of discarding such a clause. Support for incorporating a property clause centred on, inter alia, the need to anchor property rights in the Constitution so as to prevent anything slightly resembling apartheid from ever happening again and the necessity for adequately protecting existing rights. A property clause could furthermore also facilitate a legislative programme to effect restoration and rural reconstruction. ${ }^{54}$ Criticism against a property clause was levelled at the fact that it would prevent reform and would 'freeze' existing rights to the detriment of reform and transformation. It was argued here that a lasting resolution of the South African problem would be threatened if property rights were protected in the Constitution. ${ }^{55}$ After intensive debate, section 28 was finally included into the interim Constitution. According to Ntsebeza "[i]t is widely accepted that Section 28 represented a compromise between the ANC and NP positions." ${ }^{, 56}$ It was a short, concise section. Though it did not specifically provide for land reform, ${ }^{57}$ it did provide for the expropriation of property or rights in property for public purposes, with the payment of just and equitable compensation. ${ }^{58}$

Not forming part of the Bill of Rights as such, in sections 121, 122 and 123 respectively, provision was made for legislation to be drafted to regulate the restitution process, for a Commission on the Restitution of Land Rights and a court of law to adjudicate these matters. ${ }^{59}$ The restitution programme and the Land Claims Court were subsequently provided for under the Restitution of Land Rights Act 22 of 1994.

52 See especially Ntsebeza, "Land redistribution in South Africa: the property clause revisited" in Ntsebeza and Hall (eds.), The land question in South Africa 2007:108-131.

53 Van der Walt, Constitutional property law 2006:2-3; Chaskalson, "Stumbling towards section 28: negotiations over the protection of property rights in the interim Constitution" 1995 SAJHR 222-240; Ntsebeza, "Land redistribution in South Africa: the property clause revisited" in Ntsebeza and Hall (eds.), The land question in South Africa 2007:108-131; Van der Walt, "The constitutional property clause: striking a balance between guarantee and limitation" in Maclean (ed.), Property and the Constitution 1990:109-146; Murphy,

"Interpreting the property clause in the Constitution of 1993" 1995 SA Public Law 107-130.

Chaskalson, "Stumbling towards section 28: negotiations over the protection of property rights in the interim Constitution" 1995 SAJHR 222-240.

55 Ntsebeza, "Land redistribution in South Africa: the property clause revisited" in Ntsebeza and Hall (eds.) The land question in South Africa 2007:110-111.

56 Ntsebeza, "Land redistribution in South Africa: the property clause revisited" in Ntsebeza and Hall (eds.) The land question in South Africa 2007:115.

57 See for more detail Devenish, Commentary on the South African Constitution 1998:68-71.

58 Section 28(3). See also Badenhorst, Pienaar and Mostert, Law of Propertyy 2006:590-591; Carey-Miller and Pope, Land Title 2000:282-286 and Chaskelson “The property clause: section 28 of the Constitution" 1994 SAJHR 131-141.

59 Van der Merwe and Pienaar, "Land reform in South Africa" in Jackson and Wilde (eds.), Reform of property law 1997:347. 
On 4 February 1997 the interim Constitution was superceded by the final Constitution and section 28 was replaced by a new property clause, section 25 .

\section{Section 25}

\section{Background}

In the context of this contribution, focussing on land reform within a constitutional dispensation, section 25 is pivotal. Before the implications of embedding land reform within the Constitution are elaborated on in more detail below, the general approach to interpreting the provisions and the structure of the property clause are set out first. For these purposes section 25 is reproduced in full:

(1) No one may be deprived of property except in terms of law of general application, and no law may permit arbitrary deprivation of property.

(2) Property may be expropriated only in terms of law of general application:

(a) for a public purpose or in the public interest; and

(b) subject to compensation, the amount of which and the time and manner of payment of which have either been agreed to by those affected or decided or approved by a court.

(3) The amount of the compensation and the time and manner of payment must be just and equitable, reflecting an equitable balance between the public interest and the interests of those affected, having regard to all relevant circumstances, including:

(a) the current use of the property;

(b) the history of the acquisition and use of the property;

(c) the market value of the property;

(d) the extent of direct state investment and subsidy in the acquisition and beneficial capital improvement of the property; and

(e) the purpose of the expropriation.

(4) For the purposes of this section:

(a) the public interest includes the nation's commitment to land reform, and to reforms to bring about equitable access to all South Africa's natural resources; and

(b) property is not limited to land.

(5) The state must take reasonable legislative and other measures, within its available resources, to foster conditions which enable citizens to gain access to land on an equitable basis.

(6) A person or community whose tenure of land is legally insecure as a result of past racially discriminatory laws or practices is entitled, to the extent provided by an Act of Parliament, either to tenure which is legally secure or to comparable redress.

(7) A person or community dispossessed of property after 19 June 1913 as a result of past racially discriminatory laws or practices is entitled, to the extent provided by an Act of Parliament, either to restitution of that property or to equitable redress.

(8) No provision of this section may impede the state from taking legislative and other measures to achieve land, water and related reform, in order to redress the results of past racial discrimination, provided that any departure from the provisions of this section is in accordance with the provisions of section 36 (1).

(9) Parliament must enact the legislation referred to in subsection (6). 
Considering that section 28 in the interim Constitution only provided for the expropriation of property for public purposes, it was sometimes considered too limited for purposes of land reform. ${ }^{60}$ To that end section 25 specifically included the expropriation of property for public purposes as well as for in the public interest. In this light Chief Justice Mogoeng Mogoeng recently stated as follows in Agri South Africa v. Minister for Minerals and Energy and Others: ${ }^{61}$

The approach to be adopted in interpreting section 25, with particular reference to expropriation, is to have regard to the special role that this section has to play in facilitating the fulfilment of our country's nation-building and reconciliation responsibilities, by recognising the need to open up economic opportunities to all South Africans. This section thus sits at the heart of an inevitable tension between the interests of the wealthy and the previously disadvantaged. And that tension is likely to occupy South Africa for many years to come, in the process of undertaking the difficult task of seeking to achieve the equitable distribution of land and wealth to all.

\section{Structure and Clusters}

Having regard to the general approach to section 25, the actual structure thereof is important. Essentially two broad, seemingly contrasting, parts emerge: ${ }^{62}$

(a) a traditional cluster of provisions that protect existing property rights and interests, consisting of subsections (1), (2) and (3); and

(b) a second part that provides authority for state action to promote land reform and other related reforms, consisting of subsections (4)-(9).

While it is understandable that both categories (or parts) are essential, the end result is a rather complex property clause. This means that, when the property clause is considered, it automatically necessitates an understanding of the underlying tensions and potential conflicts that are embodied in section $25 .{ }^{63}$ On closer scrutiny the property clause consists of 4 clusters, comprising the following: $:^{64}$ cluster 1: deprivation - section $25(1)$; cluster 2 : expropriation - section 25(2) and (3); cluster 3: interpretation - section 25(4); and cluster 4: reforms - section 25(5)-(9). However, having regard to the clause as a whole, it is clear that the majority of the sections are aimed at reforming and transforming (subsections (4)-(9)). Even subsections (1) and (2), aimed at setting out the parameters for limiting and expropriating property, also contribute to transformation as these subsections indicate clearly that property rights may be limited and indeed expropriated - as long as it remains constitutional. ${ }^{65}$ A transformative thrust is thus clearly embodied in the property clause, elaborated on below with regard to each cluster.

\footnotetext{
60 See especially Ntsebeza, "Land redistribution in South Africa: the property clause revisited" in Ntsebeza and Hall (eds.), The land question in South Africa 2007:108-13;115.

612013 (4) SA 1 (CC) at para [60].

62 Van der Walt, Constitutional Property Law 2011:12; Cheadle, Davis and Haysom, South African Constitutional Law 2005:20-1-18; Carey-Miller and Pope, Land Title 2000:290-291.

63 Van der Walt, Constitutional Property Law 2011:16.

64 See in detail Van der Walt, Constitutional Property Law 2011:16.

65 See e.g. First National Bank of SA Ltd t/a Wesbank Commissioner, South African Revenue Service, First National Bank of SA Ltd t/a Wesbank v. Minister of Finance [2002] ZACC5; 2002 (4) SA 768 (CC).
} 
The first cluster contains section 25(1). The function of this section is twofold: firstly, it confirms that the property clause does not render property absolute and untouchable ${ }^{66}$ and secondly, it ensures that necessary and legitimate regulatory limitations are imposed, albeit not arbitrarily or unfairly. ${ }^{67}$ Essentially, this means that there has to be a good reason before rights may be limited. Accordingly, where good reasons exist, ownership and property rights may be restricted and limited. ${ }^{68}$

The second cluster deals with section 25(2) and (3) laying down the general provisions for the validity of expropriation. Expropriation is an original form of acquisition of ownership whereby the state acquires ownership without the consent of the previous owner. ${ }^{69}$ This section confirms that expropriation is legitimate if certain requirements have been met. These include that expropriation must be imposed by law of general application $;{ }^{70}$ it must serve a public purpose ${ }^{71}$ or be in the public interest; ${ }^{72}$ and it must be accompanied by just and equitable compensation. ${ }^{73}$ As alluded to above, expropriation is now also possible "in the public interest" and not for public purposes only, thereby expanding the former section 28-scope. Section 25(3) specifies that compensation has to be paid in cases of expropriation and that the amount, time and manner of payment have to be just and equitable. ${ }^{74}$ In this regard the general principles underlying expropriation are also listed, including that it should reflect an equitable balance between the interests of those affected and the public interest, having regard to all the relevant factors. These factors include: (a) the current use of the property; (b) the history of the acquisition and use of the property; (c) the market value of the property; (d) the extent of direct state investment and subsidy in the acquisition and beneficial capital improvement of the property; and (e) the purpose of the expropriation. $^{75}$

Cluster three contains section 25(4) that provides guidelines as to how section 25 is to be interpreted. In this regard Chief Justice Mogoeng Mogoeng also stated that: ${ }^{76}$

66 It is absolute if it always prevails, in all conditions and at all times.

67 This usually entails due process and reasonableness. Conversely: arbitrary conduct would normally amount to an absence of due process and unreasonableness.

68 E.g., Nhlabathi and Others v. Fick [2003] 2 All SA 323 (LCC) found that section 6(5) of the Extension of Security of Tenure Act 62 of 1997, providing for burial rights, was constitutional as it did not contravene section 25(1) or (2) of the Constitution. To that end the land owner's rights may be limited as the limitation was reasonable and justifiable in the public interest and was not arbitrary - see Pienaar and Mostert, "The balance between burial rights and landownership in South Africa: Issues of content, nature and constitutionality" 2005 SALJ 633-660.

69 This is a very common power that governments have internationally, namely to expropriate or take away property rights for very particular purposes - see Van der Walt, Constitutional Property Law 2011:334-340. See also Currie and De Waal, Bill of Rights Handbook 2005:534.

70 This means that the law should impact on everyone, on a national scale and should not affect only certain persons or communities.

71 This usually includes acquiring land in order to build schools, hospitals and roads.

72 This is more difficult to define, but is essentially broader than public purposes only. See also section 25(4). See Slade, The justification of expropriation for economic development LLD Dissertation US (2012).

73 See in general Du Plessis, Compensation for expropriation under the Constitution LLD dissertation SU (2009); Du Plessis, "Silence is golden: the lack of direction on compensation for expropriation in the 2011 Green Paper on Land Reform" 2014 PER 24.

74 See generally Du Plessis, Compensation for expropriation under the Constitution LLD dissertation SU (2009).

75 Pienaar, Land Reform 2014:177-179; Currie and De Waal, Bill of Rights handbook 2005:551-554; Van der Walt, Constitutional Property Law 2011:18-20.

76 Agri South Africa v. Minister of Minerals and Energy and Others 2013 (4) SA 1 (CC) at para [61]. 
Section 25(4)(a) enjoins the courts to bear in mind, as they interpret section 25 , that the public interest referred to in section 25(2) includes the nation's commitment to land reform and reforms to bring about equitable access to all our natural resources. We must therefore interpret section 25 with due regard to the gross inequality in relation to wealth and land distribution in the country...,"77

Cluster four contains the reform measures consisting of subsections (5)-(9). This cluster deals with land reform and other reform measures generally. This last part of the property clause is especially distinctive from section 28 of the interim Constitution. The incorporation of a set of reform-minded subsections is a clear indication that the property clause is not intrinsically linked to 'freezing' the status quo, but instead aimed at striking an equitable balance between the protection of existing (private) property (and rights) and the promotion of public interest, which includes the reform of the property regime. ${ }^{78}$

When the final Constitution commenced in February 1997, an all-encompassing land reform programme was still in the process of being unrolled, as explained, although various legislative measures pertaining to land had already been promulgated at that stage. ${ }^{79} \mathrm{With}$ respect to the three main areas of land reform constituting redistribution, tenure reform and restitution, various unrelated legislative measures were operative, with only limited progress overall. Restitution was possibly the most advanced leg of the land reform programme as it had already been established, although in a limited capacity initially, in $1991 .^{80}$ The limited scope of the process and capacity of the Commission on Land Allocation were thereafter expanded, first in the interim Constitution and later in the Restitution of Land Rights Act 22 of 1994. When the final Constitution commenced, the Commission on Restitution of Land Rights had already been established and the Land Claims Court was already operative, especially in relation to restitution matters. However, during the interim Constitution's application, the tenure reform programme had consisted mainly of the Upgrading of Land Tenure Rights Act 112 of 1991 that was promulgated under De Klerk in 1991. Correspondingly, redistribution of land had mainly been dealt with under the Provision of Land and Assistance Act 126 of 1993, also a pre-constitutional measure. Therefore, with regard to tenure reform and redistribution specifically, not much had been done at that stage. Although the pre-1994 measures remained relevant, and other measures linked to land matters had commenced, an all-encompassing land reform programme, embedded in a constitutional basis, was still lacking. The land-related provisions that were indeed contained in the interim Constitution were furthermore scattered in

77 See Mostert, "Land as a "national asset" under the Constitution: the system change envisaged by the 2011 Green Paper on Land Reform and what it means for property law under the Constitution" 2014 PER 23 for a comparison of the land reform approach to that followed with regard to the reform of minerals. See also the Mineral Petroleum Resources Development Act 28 of 2002 which is often hailed as an example of reshaping the mineral landscape in the interest of wealth redistribution.

78 Van der Walt, Constitutional Property Law 2011:41; Pienaar, Land Reform 2014:182-185. In contrast to Ntesebeza, who calls for the amendment of the property clause ("Land redistribution in South Africa: the property clause revisited" in Ntsebeza and Hall (eds.), The land question in South Africa 2007:108-131), Hall opines that the problem seems to be "more political than legal" and that, when interpreted and applied correctly, the property clause should not impact negatively on the overall land reform programme - see Hall, "Transforming rural South Africa? Taking stock of land reform" in Ntsebeza and Hall (eds.), The Land Question in South Africa 2007:87-106.

79 Including for example, the Restitution of Land Rights Act 22 of 1994.

80 Forming part of the exploratory programme under the De Klerk-Government. 
various parts ${ }^{81}$ and were lacking in focus and co-ordination. With the drafting of the fourth cluster in section 25 these short-comings were all attended to. Finally, a focused set of reform measures were all located in the same clause. In this regard sections 25(5)-(9) require further scrutiny.

\section{Reformative Thrust}

Section 25(5) places a general duty on the state to take reasonable legislative and other steps, within its available resources, to foster conditions which promote equitable access to land for citizens. In reality this subsection embodies the redistribution programme. ${ }^{82}$ Of special interest are the following considerations:

- legislation has to be drafted and other steps have to be taken specifically to effect access;

- access relates not only to agricultural or rural land. In fact, section 25(5) states that there has to be equitable access to land - generally, that would therefore include urban contexts; and

- it is the only programme that qualifies the beneficiary group, namely citizens.

Section 25(6) places a duty on the state to draft legislation to ensure that security of tenure for persons or communities whose tenure of land is legally insecure as a result of past discriminatory laws or practices, improves by providing for such security or comparable redress. This subsection embodies the tenure reform programme. Tenure reform entails changing or adjusting the basis on which control is held over land so that it is stronger and better protected against interference. ${ }^{83}$ Adjusting or amending the basis on which control is exercised over land was necessary in view of the fact that, routinely, more insecure rights were allocated to non-whites whereas more secure rights, in particular ownership, were exercised by whites. ${ }^{84}$ The tenure reform programme is also elaborated on in section 25(9) which provides that Parliament had to enact the legislation required. Of special interest are the following: ${ }^{.5}$

- individuals and communities both qualify for tenure reform opportunities;

- specific legislation has to be promulgated; and

- comparable redress is possible when reform cannot take place.

Section 25(7) entitles a person or community dispossessed of property after 19 June 1913 as a result of past racially discriminatory laws or practices to restitution or equitable redress, as provided in legislation. This subsection embodies the restitution programme. Of special interest are the following:

- the cut-off date - 19 June 1913 - is constitutionally-based;

- the process is mainly legislation-based; and

81 E.g., section 28 provided for expropriation in some instances while sections 121-123 provided for restitution of land and rights in land.

82 See Pienaar, "Reflections on the South African land reform programme: characteristics, dichotomies and tensions (Part 2)" 2014 TSAR 690-692 for an analysis of the redistribution programme's greatest shortcomings.

83 Interference also includes being evicted arbitrarily, without a legal basis.

84 See Pienaar, Land Reform 2014:151.

85 See Pienaar, "Reflections on the South African land reform programme: characteristics, dichotomies and tensions (Part 2)" 2014 TSAR 692-693 for an analysis of the shortcomings of the tenure reform programme. 
- equitable redress is possible. ${ }^{86}$

The three sub-programmes of the overall land reform programme have thus been cemented constitutionally. Under these sections numerous legislative measures ${ }^{87}$ have been promulgated to achieve the respective goals of redistribution, tenure reform and restitution and various other developments are presently also underway. ${ }^{88}$ Section $25(8)$ also ensures that no provision of section 25 may impede the state from taking legislative and other measures to achieve land, water and related reforms in order to redress the results of past racially discriminatory laws and practices, on condition that such measures are in accordance with section 36. Section 36, the limitation clause, provides that the rights in the Bill of Rights may be limited, provided that certain conditions have been met. ${ }^{89}$ This means that the right to property, like other rights in the Constitution, is not absolute. ${ }^{90}$ Therefore, section 25 , read with section 36 , indicates clearly that reform and transformation are integral components of the present South African property paradigm.

\section{Implications of having Land Reform embedded in the Constitution}

While the exploratory land reform programme was not constitutionally-based, the allencompassing (or current) land reform programme is embedded in the Constitution. Why is this important? Are there any real differences between a loose-standing programme and one embedded in the Constitution? Is there a difference between a land reform programme embedded in any part of the Constitution and one embedded within the property clause specifically? Herewith the crux of the contribution: it is not by chance that the land reform programme currently conducted in South Africa is embedded in the Constitution and located within the property clause in particular. It was a considered decision. ${ }^{91}$ This decision has important implications. These implications distinguish the South African land reform programmes from other land reform programmes conducted globally.

Having the land reform programme embedded in the Constitution immediately places various responsibilities on the government regarding the necessary steps it has to take to effect land reform. ${ }^{92}$ This means that the government cannot merely abandon land reform, it is constitutionally enjoined to attend to it meticulously. Not only is the basic responsibility grounded in the Constitution, but the broad parameters of the various programmes are set out as well. This means that adjustments and changes to land reform cannot take place outside the broad parameters of the Constitution. To some extent, the property clause therefore provides the 'framework blueprint' for the reform of property, including land reform.

86 This means that when specific restoration of property cannot take place, other equitable redress can occur, including a financial award - see also Fay and James "Giving land back or righting wrongs" in Walker, Bohlin, Hall and Kepe (eds.), Land, Memory, Reconstruction and Justice: Perspectives on land claims in South Africa 2010:41-61.

87 See Mostert, Pienaar and Van Wyk, "Land" in Joubert (ed.) LAWSA 14 2010:paras 111-174.

88 E.g., the Communal Property Associations Amendment Bill of 2014 and the Communal Land Tenure Bill of 2014.

89 Van der Walt, Constitutional Property Law 2011:21; Cheadle, Davis and Haysom, South African Constitutional Law 2005:30-1-4.

90 Currie and De Waal, Bill of Rights handbook 2005:163-168; Carey-Miller and Pope, Land title 2000:303.

91 Woolman, The Selfless Constitution 2013:318.

92 Hall, "Transforming rural South Africa? Taking stock of land reform" in Ntsebeza and Hall (eds.), The Land Question in South Africa 2007:87-106. 
On the basis that parliamentary sovereignty has been replaced by constitutional supremacy, all actions endorsing land reform stand to be tested against the Constitution. Essentially, the Constitution now acts as a big 'checks and balances' tool. ${ }^{93}$ This factor has to be considered continuously, but especially during the process of drafting new measures. It is within this context that the constitutionality of land reform and other reformative measures have to be approached. ${ }^{94}$ In this regard greater care, caution and slower processes are often better served than ex post facto unconstitutionality findings. ${ }^{95}$

Having a constitutional basis for land reform brings to the fore the technical issue as to which source of law is to be employed when a right flowing from land reform has to be enforced. For example, where restoration of land is in issue, should one use the land reform legislation - the Restitution of Land Rights Act 22 of 1994, or the common law ${ }^{96}$ or can one rely directly on the Constitution itself? In this regard particular subsidiarity rules have been developed. ${ }^{97}$ While complex, these rules essentially entail that where legislation was specifically drafted to provide content and context to particular fundamental rights, reliance should be on the legislative measure itself and not on the common law or the Constitution. Within the context of dispossession of land as a result of racially discriminatory laws or practises, the procedures and requirements set out in the Restitution Act need to be complied with meticulously. Underlying the subsidiarity rules is the idea of 'one country one law' so as to prevent confusion and a proliferation of remedies. ${ }^{98}$

Moreover, a constitutionally embedded land reform programme has clear implications for how legislative measures have to be approached, interpreted and ultimately applied. In this regard the underlying values of the Constitution also come into play, namely freedom, equality and dignity. ${ }^{99}$ Particular constitutional values underpinning land reform specifically further include the commitment to orderly land reform and ubuntu - in the sense that it is linked with humanness and dignity. ${ }^{100}$ For example, with regard to the interpretation of section 2 of the Restitution of Land Rights Act 22 of 1994, courts have placed much

93 Cheadle, Davis and Haysom, South African Constitutional Law 20-24-25.

94 E.g., the Communal Land Rights Act 11 of 2004 was eventually found to be unconstitutional on the basis that the incorrect tagging procedure was followed - see Tongoane and Others v. Minister of Agriculture and Land Affairs and Others 2010 (6) SA 214 (CC). See Claassens and Cousins (eds.), Land, Power and Custom Controversies generated by South Africa's Communal Land Rights Act (2008) for a detailed analysis of all the relevant issues. With regard to gender inequality within this context see Claassens and Ngubane, "Women, land and power: the impact of the Communal Land Rights Act" in Claassens and Cousins (eds.), Land, Power and Custom Controversies generated by South Africa's Communal Land Rights Act 2008:154-183.

95 Mosert, "Land as a "national asset" under the Constitution: the system change envisaged by the 2011 Green Paper on Land Policy and what it means for property law under the Constitution" 2014 PER 23.

96 E.g. by way of enrichment claims - see Du Plessis, The South African Law of Unjustified Enrichment 2012:21-22.

97 See for a detailed discussion hereof and for the rules themselves Van der Walt, Constitutional Property Law 2011:66-68; Pienaar, Land Reform 2014:187-188.

98 See e.g. Boggenpoel, "Does method really matter? Reconsidering the role of common law remedies in the eviction paradigm" 2014 Stellenbosch Law Review 72.

99 See also Ackermann, Human Dignity 2013:chapter 5.

100 Pienaar and Brickhill, "Land" in Woolman, Chaskelson and Bishop (eds.), Constitutional Law of South Africa 2007:48-34; Metz, "Ubuntu as a moral theory and human rights in South Africa" 2011 African Human Rights Law Journal 532-543. 
emphasis on its umbilical link with section $25 .{ }^{101}$ To that end a particular purposive approach to interpretation has resulted. ${ }^{102}$

Having land reform embedded in the Constitution also underscores the links between the property clause, section 25, and other related rights in the Bill of Rights. In this regard section 9 - the equality clause; section 10 - the right to dignity; section 26 - the right to access to housing and sections 30 and 31, respectively the right to culture and the right to belong to a cultural community, also resonate with the effective functioning of the land reform programme. ${ }^{103}$ In this regard optimal synergy between these fundamental rights and the land reform programme has unfortunately remained a challenge. It is especially with regard to equality and dignity that disconnects and dichotomies emerge. ${ }^{104}$ Achieving equality, specifically with respect to the gender dimension of land reform, which impacts on especially the redistribution and tenure reform programmes, still poses a major challenge. ${ }^{105}$ Despite initial policy guidelines indicating that women in particular had to benefit from land reform, indications are that women, for various reasons, may in fact be the least likely to benefit. ${ }^{106}$ Infusing dignity, especially within the domain of access to land and housing and correspondingly unlawful occupation and eviction, seems likewise elusive. ${ }^{107}$

While land reform is complex and multi-dimensional in that various factors and considerations guide and impact on its workings, it is clear that its constitutional dimension is paramount for its optimal functioning.

\section{Conclusion}

Embedding land reform in the Constitution was no coincidence. On the contrary, it was a considered decision - a decision that has non-negotiable implications for all role players involved. In the South African land reform context the Constitution is central: it anchors and stabilises, yet also guides and is direction-giving. This is quite unique. While providing a framework blueprint it also enables change, transformation and growth. In this regard the property clause provides the necessary parameters to protect existing land and property rights, but also enables the transformation of the South African landscape generally and property rights, in particular.

While the Constitution is integral in the South African land reform programme and centres it effectively, more is required for land reform to be effective overall: policymakers have to draft sound and clear policies, which have to be reduced to effective legislation by

101 Alexkor Ltd and Another v. Richtersveld Community and Others 2003 (12) BCLR 1301 (CC).

102 Mostert, "Change through jurisprudence: the role of the courts in broadening the scope of restitution" in Walker, Bohlin, Hall and Kepe (eds.), Land, memory, reconstruction and justice 2010:61-79;61.

103 Cheadle, Davis and Haysom, South African Constitutional Law 25-11; 25-18.

104 See Pienaar, "Reflections on the South African land reform programme: characteristics, dichotomies and tensions (Part 2)" 2014 TSAR 689-705.

105 Walker, "Elusive equality: women, property rights and land reform in South Africa" in Goldblatt and McLean (eds.), Women's Social and Economic Rights 2011:105-127.

106 Walker, "Redistributive land reform: for what and for whom?" in Ntsebeza and Hall (eds.), The land question 2007:132-151; Claassens and Mnisi, "Rural women redefining land rights in the context of Living Customary Law" in Goldblatt and McLean (eds.), Women's Social and Economic Rights: Developments in South Africa 2011:80-104.

107 Liebenberg, Socio-economic rights 2010:311; Chenwi, "A new approach to remedies in socioeconomic rights adjudication: Occupiers of 51 Olivia Road and Others v. City of Johannesburg and Others" 2009 Constitutional Court Review 371. 
competent lawmakers. These laws have to be interpreted and implemented effectively and where conflicts arise, courts need to adjudicate and to balance and weigh the conflicting rights and aspirations concisely. For land reform to be successful, the Constitution and all the other elements and components of land reform have to work together, optimally and effectively. This is no easy task. Even within a constitutional dispensation, constant vigilance and commitment are crucial.

\section{BIBLIOGRAPHY}

Ackerman L 2013. Human Dignity: Lodestar for equality in South Africa. Cape Town: Juta. Badenhorst PJ, Pienaar JM and Mostert H 2006. Silberberg and Schoeman's Law of Property. Durban: LexisNexis.

Beinart W 2001. Twentieth Century South Africa New York: Oxford University Press.

Bennett T 1996. "African land - a history of dispossession" in Zimmermann R and Visser D (eds.). Southern Cross. Cape Town: Juta 65-94.

Boggenpoel ZT 2014. "Does method really matter? Reconsidering the role of common law remedies in the eviction paradigm". Stellenbosch Law Review 72-83.

Bohlin A 2004. "A price on the past: Cash as compensation in South African land restitution”. Canadian Association of African Studies 672-687.

Carey-Miller DL and Pope A 2000. A Land Title in South Africa. Kenwyn: Juta.

Chaskalson M 1995. "Stumbling towards section 28: Negotiations over the protection of property rights in the interim Constitution". SAJHR 222-240.

Chaskelson M 1994. "The property clause: section 28 of the Constitution". SAJHR 131-141.

Cheadle MH, Davis DM and Haysom NRL 2005. South African Constitutional Law: The Bill of Rights, Durban: LexisNexis.

Chenwi L 2009. "A new approach to remedies in socioeconomic rights adjudication: Occupiers of 51 Olivia Road and Others v. City of Johannesburg and Others". Constitutional Court Review 371-382.

Claassens A and Mnisi S 2011. "Rural women redefining land rights in the context of Living Customary Law" in Goldblatt B and McLean K (eds.) Women's Social and Economic Rights: Developments in South Africa. Cape Town: Juta 80-104.

Claassens A and Ngubane S 2008. "Women, land and power: the impact of the Communal Land Rights Act" in Claassens A and Cousins B (eds.) Land, Power and Custom Controversies generated by South Africa's Communal Land Rights Act. Cape Town: UCT Press 154-183.

Cobbett M 1988. "The land question in a post-apartheid South Africa: A preliminary assessment" in Cross C and Haines R (eds.) Towards Freehold? Options for Land and Development in South Africa's Black Rural Areas. Cape Town: Juta 60-72.

Currie I and De Waal J 2005. The Bill of Rights Handbook 5 (ed.). Landsdowne: Juta. Department of Rural Development and Land Reform 2013. Policy Framework for the Recapitalisation and Development Programme 23 July.

Department of Rural Development and Land Reform 2013. State Land Lease and Disposal Policy Framework 23 July. 
Department of Rural Development and Land Reform 2013. Agricultural Landholding Policy Framework 23 July.

Devenish GE 1998. A Commentary on the South African Constitution. Durban: Butterworths.

Dorner P 1992. Latin American Land Reforms in Theory and Practice. Madison: University of Wisconsin Press.

Du Plessis JE 2012. The South African Law of Unjustified Enrichment. Cape Town: Juta.

Du Plessis WJ 2009. Compensation for expropriation under the Constitution LLD dissertation. University of Stellenbosch.

Du Plessis WJ 2014. "Silence is golden: the lack of direction on compensation for expropriation in the 2011 Green Paper on Land Reform" 2014 PER 24.

Du Toit A 2011."Comment on the newly released Green Paper on Land Reform” 26 September 2011, PLAAS.

Fay D and James D 2010. "Giving land back or righting wrongs" in Walker C, Bohlin A, Hall R and Kepe T (eds.). Land, Memory, Reconstruction and Justice: Perspectives on land claims in South Africa. Ohio: Ohio University Press and Pietermaritzburg: University of KwaZulu-Natal Press 41-61.

Feinstein CH 2005. Economic History of South Africa. Cambridge: Cambridge University Press.

Gibson JL 2010. "Land redistribution/restitution in South Africa: a model of multiple values as the past meets the present". British Journal of Political Science 135-169.

Gibson JL 2008. Overcoming historical injustices: land reconciliation in South Africa. New York and Cambridge: Cambridge University Press.

Giliomee H 2003. The Afrikaners: Biography of a People. Cape Town: Tafelberg.

Hall R 2007. "Transforming rural South Africa? Taking stock of land reform" in Ntsebeza L and Hall R (eds.) The Land Question in South Africa - The challenge of transformation and redistribution. Cape Town: HSRC Press 87-106.

Hall R 2010. "Reconciling the past, present and future" in Walker C, Bohlin A, Hall R and Kepe T (eds.) Land, Memory, Reconstruction and Justice: Perspectives on Land Claims in South Africa. Ohio: Ohio University Press and Pietermaritzburg: University of KwaZulu-Natal Press 17-40.

Huchzermeyer M 2004. "From 'contravention of laws' to 'lack of rights': redefining the problem of informal settlements in South Africa". Habitat International 333-347.

Klopper H and Pienaar GJ 2014. "The historical context of land reform in South Africa and early policies" 2014 PER $201-21$.

Langford M and Moyo K 2010. "Right, remedy or rhetoric? Land restitution in international law”. Nordic Journal of Human Rights 143-176.

Lipton M 2011. Land reform in developing countries: Property rights and property wrongs. New York: Routledge.

Marais H 2011. South Africa Pushed to the limit: the political economy of change. London: Zed Books.

Metz T 2011. "Ubuntu as a moral theory and human rights in South Africa". African Human Rights Law Journal 532-543. 
Mostert H 2010. "Change through jurisprudence: the role of the courts in broadening the scope of restitution" in Walker C, Bohlin A, Hall R and Kepe T (eds.) Land, memory, reconstruction and justice. Ohio: Ohio University Press and Pietermaritzburg: University of KwaZulu-Natal Press 61-79, 61.

Mosert H 2014. "Land as a "national asset" under the Constitution: the system change envisaged by the 2011 Green Paper on Land Reform and what it means for property law under the Constitution" 2014 PER 23.

Mostert H, Pienaar JM and Van Wyk J 2010. "Land" in Joubert WA (ed) LAWSA 14. Durban: LexisNexis.

Muller G 2013. "The legal-historical context of urban forced evictions in South Africa". Fundamina 367-396.

Murisa T and Helliger K 2011. "Contemporary rural realities in Southern Africa" in Helliger K and Murisa T (eds.) Land struggles in Civil Society in Southern Africa. Trenton, NJ: Africa World Press 1-43.

Ntsebeza L 2007. "Land redistribution in South Africa: the property clause revisited" in Ntsebeza L and Hall R (eds.) The Land Question in South Africa - The challenge of transformation and redistribution. Cape Town: HSRC Press 107-131.

Olivier NJJ, Du Plessis W and Pienaar JM 1990. "Legislation affecting land: an overview". SA Public Law 266-276.

Pienaar JM and Brickhill J 2007. "Land" in Woolman S and Bishop M (eds.) Constitutional Law of South Africa. Cape Town: Juta Chapter 48.

Pienaar JM and Mostert H 2005. "The balance between burial rights and landownership in South Africa: Issues of content, nature and constitutionality”. SALJ 633-660.

Pienaar JM 2014. "Reflections on the South African land reform programme: characteristics, dichotomies and tensions (Part 2)". TSAR 689-705.

Pienaar JM 2014. Land Reform. Cape Town: Juta.

Reilly A 2001. "Land rights for disenfranchised and dispossessed peoples in Australia and South Africa: a legislative comparison". Queensland Law Journal 41-56.

Slade B 2012. The justification of expropriation for economic development LLD Dissertation. University of Stellenbosch.

Sparks A 1990. The Mind of South Africa: The story if the rise and fall of Apartheid (1990 - reprinted 2007). Cape Town and Johannesburg: Jonathan Ball Publishers.

Van der Merwe D 1989. "Land tenure in South Africa: a brief history and some reform proposals". TSAR 663-692.

Van der Merwe CG and Pienaar JM 1997. "Land reform in South Africa" in Jackson P and Wilde DC (eds.) Reform of Property Law. Dartmouth: Dartmouth Publishing Company 334-380.

Van der Walt AJ 1990. "Towards the development of post-apartheid land law: an exploratory survey". 23 De Jure 1-45.

Van der Walt AJ 1999. "The constitutional property clause: striking a balance between guarantee and limitation" in McLean J (ed.) Property and the Constitution. Oxford: Hart Publishing.

Van der Walt AJ 2006. Constitutional Property Law 2 ed. Cape Town: Juta.

Van der Walt AJ 2011. Constitutional Property Law 3 ed. Cape Town: Juta. 
Van der Westhuizen C 2005. "Land reform: lessons from a south-eastern Free State experience". SA Tydskrif vir landbouvoorligting 1-10.

Van Wyk J 2012. Planning Law. Cape Town: Juta.

Walker C 2011. "Elusive equality: women, property rights and land reform in South Africa" in Goldblatt B and McLean K Women's Social and Economic Rights: Developments in South Africa. Cape Town: Juta 105-127.

Walker C 2007. "Redistributive land reform: for what and for whom?" in Ntsebeza L and Hall R (eds.) The Land Question in South Africa - The challenge of transformation and redistribution. Town: HSRC Press 132-151.

Woolman S and Swanepoel J 2009. "Constitutional History” in Woolman S, Roux T and Bishop M (eds.) Constitutional Law of South Africa volume 1, second edition Cape Town: Juta Chapter 2.

Woolman S 2009. “Application” in Woolman S, Roux T and Bishop M (eds.) Constitutional Law of South Africa. Volume 1, second edition Cape Town: Juta Chapter 31.

Woolman S 2013. The Selfless Constitution. Cape Town: Juta.

\section{LEGISLATION}

Abolition of Racially-Based Land Measures Act 108 of 1991.

Group Areas Act 41 of 1950.

Mineral Petroleum Resources Development Act 28 of 2002.

Natives (Urban Areas) Act 21 of 1923.

Natives (Urban Areas) Consolidation Act 25 of 1945.

Prevention of Illegal Eviction from and Unlawful Occupation of Land Act 19 of 1998.

Prevention of Illegal Squatting Act 52 of 1951.

Restitution of Land Rights Act 22 of 1994.

Upgrading of Land Tenure Rights Act 112 of 1991.

\section{CASE LAW}

Agri South Africa v. Minister for Minerals and Energy and Others 2013 (4) SA 1 (CC).

Alexkor Ltd and Another v. Richtersveld Community and Others 2003 (12) BCLR 1301 (CC).

Ex Parte Chairperson of the Constitutional Assembly: In re Certification of the Constitution of the Republic of South Africa 1996 (4) SA 744 (CC).

Port Elizabeth Municipality v. Various Occupiers 2004 (12) BCLR 1268 (CC); Port Elizabeth Municipality v. Various Occupiers 2005 (1) 217 (CC).

Tongoane and Others v. Minister of Agriculture and Land Affairs and Others 2010 (6) SA 214 (CC). 